IZA DP No. 4277

The Responsiveness of Remittances to the Oil Price: The Case of the GCC

George Naufal

Ali Termos

July 2009 


\title{
The Responsiveness of Remittances to the Oil Price: The Case of the GCC
}

\author{
George Naufal \\ American University of Sharjah \\ and IZA \\ Ali Termos \\ American University of Sharjah
}
Discussion Paper No. 4277
July 2009

IZA
P.O. Box 7240
53072 Bonn
Germany

Phone: +49-228-3894-0

Fax: +49-228-3894-180

E-mail: iza@iza.org

\begin{abstract}
Any opinions expressed here are those of the author(s) and not those of IZA. Research published in this series may include views on policy, but the institute itself takes no institutional policy positions.

The Institute for the Study of Labor (IZA) in Bonn is a local and virtual international research center and a place of communication between science, politics and business. IZA is an independent nonprofit organization supported by Deutsche Post Foundation. The center is associated with the University of Bonn and offers a stimulating research environment through its international network, workshops and conferences, data service, project support, research visits and doctoral program. IZA engages in (i) original and internationally competitive research in all fields of labor economics, (ii) development of policy concepts, and (iii) dissemination of research results and concepts to the interested public.
\end{abstract}

IZA Discussion Papers often represent preliminary work and are circulated to encourage discussion. Citation of such a paper should account for its provisional character. A revised version may be available directly from the author. 
IZA Discussion Paper No. 4277

July 2009

\section{ABSTRACT \\ The Responsiveness of Remittances to the Oil Price: The Case of the GCC}

We investigate the responsiveness of remittances from the Gulf Cooperation Council (GCC) countries to the changes in the price of crude oil. Most of the GCC countries rank in the top 20 remitting countries in the world. We find that oil price elasticity of remittances is around 0.4. While most studies have examined the impact of remittances on the real economic activities in the receiving countries, this study emphasises the impact of remittances on the remitting countries. We examine various policy implications with regard to macroeconomic shocks, monetary policy and fiscal policy of the GCC countries.

JEL Classification: F24, P22, N15

Keywords: elasticity, remittances, oil price, GCC

Corresponding author:

George Naufal

American University of Sharjah

School of Business and Management

P.O. Box 26666

Sharjah

United Arab Emirates

E-mail: gnaufal@aus.edu 


\section{Introduction}

Over the last two decades world-wide remittances have been increasing tremendously. The increase in the stock of international migrants and the reduction in the cost of transferring money have spurred a significant surge in the international flow of migrant's remittances. Recent estimates by the World Bank indicate that remittances flows in 2007 exceed \$ 300 billion. ${ }^{1}$ Values of remittances are based on official estimates by the countries' Central Banks and the World Bank. The monetary transfers that are not channeled through financial institutions and other formal channels (such as Western Union) go undocumented. Therefore the official values are generally an underestimate of the actual remittances.

The significant amount of these monetary flows induced researchers and policy makers to further study remittances. While some of these studies mainly discuss the determinants of these flows (El-Sakka, M. and McNabb, R. (1999), Vargas-Silva (2008)) others have focused on the consequences of remittances on either the real macroeconomic activities (Amuedo-Dorantes and Pozo (2004), Chami et al (2005)) economic growth (Osili (2007), Giuliano and Ruiz-Arranz (2008), Gupta et al (2009)) or on the microeconomic levels (household level) (Edwards and Ureta (2003), Amuedo-Dorantes and Pozo (2006)). In summary, the literature on remittances has focused on the effects of remittances on the receiving countries. To the best of our knowledge, no study has ever discussed the effects of remittances on the remitting countries. Consequently, the literature has been focusing on the destination rather than the source. In this study, we aim to shed some light on remittances' effect on the remitting economies taking advantage of the fact that remittances in the region of study represent a significant proportion of that region's GDP. This paper contributes to the remittances literature in two ways: first it investigates remittances effects on the economies of the remitting country, and second, it examines remittances in the Middle East, namely the Gulf region which that has been largely understudied mainly due to lack of data. Specifically, 
we examine the responsiveness of remittances to the price of crude oil using data from the Gulf Cooperation Council (GCC) countries. Given the high dependence of these economies on oil revenue, a higher price of oil instigates more investment and consequently higher economic growth. This increase in aggregate demand is met with a parallel increase in demand for labour (both skilled and unskilled) and is translated into more income for expatriates and a surge in remittances.

\section{Background}

The GCC countries comprise Bahrain, Kuwait, Oman, Qatar, Saudi Arabia, and United Arab Emirates. These countries have experienced a strong economic growth in the last three decades. For instance, the GCC mean annual Gross Domestic Product (GDP) growth rate for the period between 2002 and 2006 ranges between 2.1 per cent to 9.4 per cent with an average of 6.5 per cent (Migration and Remittances, Factbook 2008). A driving force behind this growth is an increasingly growing labour force that is mainly constituted of expatriates from all over the world. A unique feature of the GCC countries is that they have been pegging their various currencies to the US dollar since the early 1970s, when the US abolished the Gold Standard and the US dollar was adopted as the official trading currency of oil. Since then the GCC economies follow closely the US monetary policy. They cut interest rate when the Federal Reserve Bank eases and they raise it when the Fed tightens regardless whether these policies are suitable for these economies at the time of execution. It is not then surprising that interest rates in GCC countries show tandem volatility with the Federal Funds Rate (Figure 1$).^{2}$ Net exports are expected to amplify when oil prices peak as GCC depend mainly on oil exports. This is shown in particular in the late 1970s and early 1980s and again in the 2000s (Figure 2).

In most countries, migrants do not constitute the majority of the total population. However, the GCC countries are unique in this regard since the expatriates population 
constitute on average more than 50 per cent of the total population with the highest being Qatar (78.3\%) and the lowest is Oman (24.5\%). In addition, four of GCC countries are among the top 10 countries in the world in terms of migrants as in terms of percentage of total population. These are Qatar $\left(1^{\text {st }}\right)$, United Arab Emirates $\left(3^{\text {rd }}\right)$, Kuwait $\left(5^{\text {th }}\right)$ and Bahrain $\left(10^{\text {th }}\right)$ (Figure 3).

The strong presence of large migrant population makes the GCC countries among the largest remitting countries both in terms of total value and in terms of percentage of GDP despite their relative small-size economies. For instance, Saudi Arabia was the second top remitting country in the World in 2006 with an estimated value of remittances close to \$ 16 billion, placing it next to the United States. Kuwait, Oman and Bahrain all show up in the top 30 sender countries in terms of remittances. Bahrain ranks $4^{\text {th }}$ in the World as a top remittance sender country with remittances equal to 12 per cent of its GDP. Saudi Arabia and Kuwait both remit five per cent and four per cent worth of their GDP and rank $9^{\text {th }}$ and $12^{\text {th }}$ respectively. Table 1 exhibits the total estimate of remittances from GCC in 2006 which is around \$ 32.7 billion. The official estimate by the World Bank for total world remittances in 2006 is \$ 306 billion of which 11 per cent come out of the GCC countries.

The significant economic growth of the GCC countries in the last decade has triggered a large interest in this region. Analyzing the volatility of remittances from the Gulf will allow the governments of the GCC countries to weigh the overall outcomes of decreasing oil prices on the real activities of their economies. The latest global financial crisis and the sudden decline in oil prices highlight the need of such studies in order for policy makers to be able to stabilise output and prices.

This remarkable growth that the GCC countries have experienced is also explained by an enormous demand for crude oil. The GDP of these countries closely follow the price of oil. Although the GCC countries have been diversifying their economies and moving away 
from their full dependence on oil revenue, oil prices still play a major role in the performance of these economies (Fasano and Iqbal (2003)). Therefore, we expect that any changes in the price of oil are directly reflected in the remittances outflow of these countries. A natural question that comes up here is: how responsive remittances are to price oil variations? In the rest of this paper we try to answer this question empirically by examining the cross elasticity of remittances from the GCC economies to price of oil. But first we present the data and methodology in the following section.

\section{Data and Methodology}

We collect data from three main sources; the World Development Indicators of the World Bank (WDI), the International Financial Statistics (IFS) of the International Monetary Fund, and the Arab Monetary Fund database. The data includes remittances, GCC government spending, GDP per capita of the world, price of crude oil and the US federal fund rate. ${ }^{3}$ Using aggregate remittances raises a number of difficulties. First, some difficulties relate to the consistency of reporting as different countries use different labeling for remittances transactions. Second, a significant portion of remittances are sent through informal channels and consequently go undocumented. Particularly in the GCC countries, a popular informal channel is what so called "Hawala" which means "a money transfer". Under Hawala, the money is transferred opaquely through a network of agents operating between the two countries, the sending and the receiving end. For these reasons we use a more inclusive and clearer measure of remittances that is reported under the Worker's Remittances and Compensation rather than the one reported in the balance of payments. In total, we have an unbalanced panel data of six countries with annual data between 1971 and 2004 which sums up to 130 observations. Table 2 presents the descriptive statistics of the remittances and GDP per capita variables along with the data availability for each country. Qatar has the highest GDP per capita and highest remittances per capita of all the GCC countries (around \$2,300), 
followed by the UAE and Bahrain. Figure 4 shows the trend of the mean of remittances per capita from 1971 to 2004. The remittances per capita have been increasing in a steady manner except for the First Gulf War in 1991 and the September 11 attacks of 2001. Figure 5 depicts the trends of the percentage change in remittances versus the percentage change in price of oil. Both variables tend to move largely in tandem except for incidents of drop in remittances during major political or military engagements in the Middle East in the past three to four decades.

The pegging of GCC currencies to the dollar and the full dependence on oil exports have deprived these countries of exerting full fledge monetary and fiscal policies. ${ }^{4}$ Interest rates follow closely the benchmark policy rate in the US, the federal funds rate (FFR), and central banks orchestrate money supply to maintain the pegged exchange rates. In addition, these economies have enjoyed budget surpluses throughout the many years of high prices of oil, which allowed them not only to exempt their citizens from any sort of taxes but also to provide subsidies in various ways (for example allowance for housing, marriage gifts, and free land). Thus fiscal policy is confined to government spending. Remittances from these economies in large sums pose a challenge to both monetary policy and fiscal policy as well. This monetary leakage mitigates the efficacy of investment and spending multipliers. We further discuss the ramifications of these effects below.

Given the issues discussed above, we set up a reduced form model of the following specification:

$$
R=f(P ; G D P \text { Other; Gov Spending; Fund Rate })
$$

Where $R$ is the amount of remittances per capita sent from the GCC countries, $P$ the price of crude oil, GDP Otherrepresents the GDP per capita of the receiving countries, Gov Spending represents the GCC governments' per capita spending, and Fund Rate is the United States federal funds rate. The economic performance of the GCC economies has been 
reliant on oil export receipts and therefore, one would expect that the higher the price of crude oil, the higher the aggregate demand, and hence the higher the remittances. This dynamic simply signifies that more expatriates leads to more remittances being sent to the countries of origin. Furthermore, the literature on remittances has examined the relationship between the receiving countries' GDP growth and the amount of money being remitted from abroad. This relationship depends on the primary motivation behind remitting whether altruism or self-interest. Remittances are expected to be positively related to the GDP growth of the receiving country if self-interest is the main force while in other studies these two variables are found to be negatively related if altruism is the main motivation to remit (Chami et al (2006)). We include government spending to control for fiscal policy and the federal funds rate to control for monetary policy. Most of the macro projects in the GCC countries are government funded (or funded through semi-government corporations) and therefore most of the income received by the expatriates is directly related to government expenditures. In order to capture the elasticity of remittances with respect to the price of oil we examine the following log-linear equation:

$$
\begin{aligned}
& \ln \left(R_{i t}\right)=\beta_{0}+\beta_{1} \ln \left(P_{i t}\right)+\beta_{2} \ln \left(\text { GDP } \text { Other }_{i t}\right)+ \\
& \beta_{3} \ln (\text { GOV Spending } i t)+\beta_{4} \text { US Fund Rate } \text { Fu }_{t}+\varepsilon_{i t}
\end{aligned}
$$

Where $R_{i t}$ represents remittances per capita sent from country $i, G D P_{i t}$ represents the per capita gross domestic product of the world, $P_{i t}$ is the price of crude oil, GOV Spending $g_{i t}$ is the per capita government expenditure of the GCC countries and US Fund Rate is the US federal funds rate all at time $t$. All variables are in per capita terms in order to control for population and specifically for the increase in the growth of expatriates as percentage of the GCC population. Also, all variable are in real terms. Our main objective is to estimate $\beta_{1}$. As outlined above, we expect a positive relationship between the price of crude oil and remittances $\left(\beta_{1}>0\right)$. We postulate that if we can formulate a better understanding of the 
variations of remittances effects on the Gulf economies, policy makers will be better equipped to devise proper monetary policy that overcomes the difficulties inherited by the attachment of domestic interest rates to the FFR and to some extent offset the deficiency of fiscal policy inflicted by the absence of a taxing system.

\section{Results}

The results of equation (2) are presented in Tables 3 and 4. Both results of ordinary least squares (OLS) and fixed effects (FE) are reported. All coefficients are reported with robust standard errors in parenthesis.

The coefficients of the price of oil which are at the center of our study, in both specifications are positive and significant. These are 0.37 (for OLS) and 0.24 (FE). The fact that the elasticity of per capita remittances with respect to price of oil is under 0.5 suggests that the response of remittances to price of oil is inelastic. However, this inelasticity of percapita remittances to price of oil is robust to both estimation techniques.

Table 3 also presents the elasticity of remittances with respect to the GDP of the world and to government spending. The positive relationship between remittances and the GDP world suggests that remittances from the expatriates in the GCC to their home countries are driven by self-interest rather than by altruism. The responsiveness of these flows is very large (the elasticity is larger than three). As for the sensitivity to fiscal policy, the per-capita government spending does not seem significant when we use FE specification as compared to OLS. Thus result suggests that GCC economies differ in their fiscal policies efficacy for when we control for each country's effect the coefficient on government spending got weakened. This result suggests that the spending multipliers across the GCC countries vary with various levels of remittances. If the country is ranked high on remittances as percentage of its GDP (for example Bahrain), leading to high monetary leakages, then one expects a lower government spending multiplier in this economy. In this case the government needs to 
make additional spending to curb a recession and a slight reduction in spending than desirable in order to mitigate inflation.

The positive and significant coefficient of the US federal fund rate indicates that an increase in the US interest rate raises the per capita remittances from the GCC countries. An increase in the interest rate signals a contractionary monetary policy in the US and is usually a response to an expansionary US economy. Therefore, remittances from the gulf region seem to respond to business cycles of the US economy through the arbitration of the price of oil.

One could argue that remittances are directly related to the GDP per capita of the World since an increase in the World economic activities generally means that people have higher income and therefore remit more money. Table 4 substitutes the GDP per capita of the World with the GDP per capita of three regions; East Asia and Pacific, South Asia and Sub Saharan Africa. These three regions combined cover the majority of the main countries of origin of the labour force or expatriates in the GCC (Philippines under East Asia and Pacific; Bangladesh, India, Pakistan, Nepal and Sri Lanka under South Asia and Sudan under Sub Saharan Africa). The results shown in Table 4 conform to those of Table 3 in that the elasticity of remittances per capita is between 0.55 (OLS) and 0.35 (FE), where the OLS estimations seem to represent an upper bound while the FE estimations represent a lower bound for the elasticity. The coefficients for the government spending and the US Federal Fund rate mimic those in Table 3 except that they both lose significance under FE. The interesting finding in Table 4 is the sign on the GDP per capita of the three regions: positive for East Asia and Pacific and negative for both South Asia and Sub Saharan Africa. The difference in signs suggests disparity in the effect of remittances on economic growth in the receiving regions and could be indicative of diverse motives of remitting across expatriates in the GCC. 
To summarise, this paper highlights the large amounts of remittances from the GCC countries and their response to price of oil changes. In what follows we highlight the major concerns of the impact of the outflow remittances of GCC on their economies.

1. Pressure on exchange rates: remitting money home by expatriates distorts the market of exchange rate by placing pressure on foreign reserves. As GCC countries peg their currencies to the US dollar, by remitting money, the expatriates are converting the local currency into their home currency or into a more easily converted and widely accepted currency like the dollar or the euro. Thus exerting additional pressure on GCC central banks to keep high foreign reserves in order to maintain the pegged exchange rate.

2. Pressure on fiscal policy: given the sheer size of the money fleeing the economy, it is expected that this would weaken the efficacy of the fiscal policy. The growing size of these remittances adds downward pressure on the government spending multiplier. In other words, when the government plans to boost spending in case of recession, this spending level should be relatively higher to offset the remittances leakage.

3. Pressure on monetary policy: as the monetary policy of the GCC countries is closely linked to the US monetary policy because of the pegging of their currencies to the dollar, interest rates volatility follows that of the United States. However, the pressure of remittances is felt on the money supply and therefore on the money multiplier. The lack of the Open Market Operations in the Gulf economies (that is the selling of government bonds to the public) can be thought of as the same as remittances outflow in terms of reducing money supply to curb inflation for example. However, one major difference is that remittances leave the economy for good and is therefore not circulated within the borders of the domestic economy as 
in the case of the Open Market Operations. Also, the other difference is that the GCC countries have neither control over the timing nor the magnitude of the remittance operations. This issue gets more malleable when the GCC economies get united under one monetary union issuing a single currency.

4. Pressure on investment. The lack of re-investing opportunities of expatriates' income in most GCC economies (for example prohibition of owning property by expatriates) hinders the real economic activity. Given that the money generated in these countries is not fully recycled domestically puts a downward pressure on the investment multiplier.

\section{Conclusion}

This paper presents an empirical exercise to estimate the elasticity of remittances with respect to price of crude oil. The literature on remittances has studied extensively the determinants and consequences of remittances in the receiving countries. However, there is a wide gap in the literature regarding remittances effect on the remitting countries. This paper contributes to the remittances literature by examining the elasticity of remittances with respect to price of crude oil. We focus on the GCC countries since most of these countries are considered top ten senders of remittances by either the value of remittances or by percentage of GDP. The response of remittances to changes in price of oil is inelastic (less than 0.5). The GCC countries can use this information to predict the magnitude of remittances sent by expatriates following any shock to the price of crude oil such as the last financial crisis. Unraveling the importance of remittances on the GCC economies allows policy makers and investors to better identify the implications on fiscal policy, monetary policy, exchange rates, and investment. Furthermore, this study outlines the types of pressures that remittances might impose on the sending countries: pressures on exchange rates, investment, fiscal and 
monetary policy. Quantifying these pressures is of great interest but we leave this issue for future research. 


\section{Notes}

1. Migration and Remittances Factbook, 2008.

2. Interest rates for UAE are not publicly available.

3. The source and definitions of the variables are presented in the Appendix.

4. With the exception of Kuwait which has abolished pegging to the dollar in favour of a basket of currencies. Local experts believe that the dollar has the largest weight in the Kuwaiti basket of currencies but these allegations have not been confirmed or rejected by the Kuwaiti government. 


\section{References}

Amuedo-Dorantes, C. and Pozo, S. (2004) Worker's Remittances and the Real Exchange Rate: A Paradox of Gifts. World Development, 32, pp. 1407-1417.

Amuedo-Dorantes, C. and Pozo, S. (2006) Migration, Remittances and Male and Female Employment Patterns. American Economic Review 96(2), pp. 222-226.

Arab Monetary Fund. Arab Monetary Fund Online Database www.amf.org.ae

Chami, R., Fullenkamp, C., Jahjah, S. (2005) Are Immigrant Remittance Flows a Source of Capital for Development? IMF-Working Paper 52(1), pp. 55-81

Chami, R., Cosimano, T. and Gapen, M. (2006) "Beware of Emigrants Bearing Gifts: Optimal Fiscal and Monetary Policy in the Presence of Remittances" International Monetary Fund Working Paper WP/06/61.

Edwards, A. and Ureta, M. (2003) International migration, remittances, and schooling: evidence from El Salvador. Journal of Development Economics, 72(2), pp. 429-461

El-Sakka, M. and McNabb, R. (1999) The Macroeconomic Determinants of Migrant Remittances. World Development, 27, pp. 1493-1502.

Fasano, U. and Iqbal, Z. (2003) GCC Countries: From Oil Dependence to Diversification. (International Monetary Fund)

Giuliano, P. and Ruiz-Arranz, Marta. (2008) Remittances, financial development, and growth. Journal of Development Economics, In Press

Gupta, S., Patillo, C. and Wagh, S. (2009) Effects of Remittances on Poverty and Financial Development in Sub-Saharan Africa. World Development, 37(1), pp. 104 - 115

Jadhav, N. (2003) Maximising Developmental Benefits of Migrant Remittances: The Indian Experience. Presented at the International Conference on Migrant Remittances, London 2003.

Osili, U. O. 2007. Remittances and savings from international migration: Theory and evidence using a matched sample. Journal of Development Economics, 83, pp. 446 - 465

Vargas-Silva, C. (2008) Crime and Remittance Transfers. Eastern Economic Journal, Forthcoming

World Bank. World Development Indicators www.worldbank.org/data/onlinedatabases 
Table 1: Remittances Values from the GCC 2006

\begin{tabular}{ccccc}
\hline Country & $\begin{array}{c}\text { Remittances Sent } \\
\$ \text { Billion }\end{array}$ & Rank in the World & $\begin{array}{c}\text { Remittances Sent } \\
\text { Percent of GDP }\end{array}$ & Rank in the World \\
\hline Bahrain & 1.5 & $30^{\text {th }}$ & 12 & $4^{\text {th }}$ \\
Kuwait & 3.0 & $18^{\text {th }}$ & 4 & $12^{\text {th }}$ \\
Oman & 2.8 & $21^{\text {st }}$ & $5.8^{*}$ & - \\
Qatar & $3.7 \wedge$ & - & - & - \\
Saudi Arabia & 15.6 & $2^{\text {nd }}$ & 5 & $9^{\text {th }}$ \\
UAE & $6.1^{\wedge}$ & - & - & - \\
\hline
\end{tabular}

Notes: 1. The source is Migration and Remittances, Factbook 2008. 2.* is for 2007. 3. ^ The source is Arab Monetary Fund online database. 
Table 2: Remittances in Total Values and in Per Capita, GDP per Capita

\begin{tabular}{|c|c|c|c|c|}
\hline Country & Variable & Mean & Min & Max \\
\hline Bahrain & Remittances Sent in \$ Billion & $6.34 \mathrm{e}+08$ & $3.30 \mathrm{e}+08$ & $1.29 \mathrm{e}+09$ \\
\hline$(1980-2004)$ & Remittances per Capita in \$ & 1184.1 & 637.1 & 1935.6 \\
\hline Obs. $=25$ & GDP Per Capita in \$ & 10874.6 & 8764 & 13988.5 \\
\hline Kuwait & Remittances Sent in \$ Billion & $1.17 \mathrm{e}+09$ & $2.76 \mathrm{e}+08$ & $2.40 \mathrm{e}+09$ \\
\hline $\begin{array}{c}(1975-1989 \text { and } \\
1995-2004)\end{array}$ & Remittances per Capita in \$ & 617.0 & 274.0 & 976.9 \\
\hline Obs. $=25$ & GDP Per Capita in \$ & 18150.6 & 11883.3 & 27113.6 \\
\hline Oman & Remittances Sent in \$ Billion & $9.60 \mathrm{e}+08$ & $1.11 \mathrm{e}+08$ & $1.83 \mathrm{e}+09$ \\
\hline$(1974-2004)$ & Remittances per Capita in \$ & 502.2 & 126.8 & 736.5 \\
\hline Obs. = 31 & GDP Per Capita in \$ & 6760.7 & 3792.6 & 9497.5 \\
\hline Qatar & Remittances Sent in \$ Billion & $1.56 \mathrm{e}+09$ & $1.26 \mathrm{e}+09$ & $2.18 \mathrm{e}+09$ \\
\hline$(1999-2004)$ & Remittances per Capita in \$ & 2308.2 & 2132.9 & 2846.8 \\
\hline Obs. $=6$ & GDP Per Capita in \$ & 28824.8 & 21005 & 41755 \\
\hline Saudi Arabia & Remittances Sent in \$ Billion & $8.50 \mathrm{e}+09$ & $2.07 \mathrm{e}+08$ & $1.81 \mathrm{e}+10$ \\
\hline$(1971-2004)$ & Remittances per Capita in \$ & 510.3 & 34.5 & 1002.9 \\
\hline 8Obs. = 34 & GDP Per Capita in \$ & 11026.5 & 8439.7 & 16428.9 \\
\hline UAE & Remittances Sent in \$ Billion & $3.79 \mathrm{e}+09$ & $3.13 \mathrm{e}+09$ & $4.65 \mathrm{e}+09$ \\
\hline$(1996-2004)$ & Remittances per Capita in \$ & 1180.9 & 1131.8 & 1257.8 \\
\hline Obs. $=9$ & GDP Per Capita in \$ & 22774.4 & 21703.9 & 24339.2 \\
\hline Sample & Remittances Sent in \$ Billion & $3.13 \mathrm{e}+09$ & $1.11 \mathrm{e}+08$ & $1.81 \mathrm{e}+10$ \\
\hline Obs. $=130$ & $\begin{array}{r}\text { Remittances per Capita in \$ } \\
\text { GDP Per Capita in \$ }\end{array}$ & $\begin{array}{c}787.9 \\
130356\end{array}$ & 34.54 & 2846.8 \\
\hline
\end{tabular}

Notes: Remittances for Qatar and UAE are from the Arab Monetary Fund online databases. The GDP per capita for Qatar is also from the Arab Monetary Fund. The remaining variables are from the World Development Indicators. 
Table 3: Elasticity of Remittances: GDP Per Capita World

\begin{tabular}{lcc}
\hline Variable & OLS & FE \\
Price of Oil & $0.373^{* * *}$ & $0.240^{* *}$ \\
& $(0.110)$ & $(0.083)$ \\
GDP per Capita World & $3.483^{* * *}$ & $2.902 * * *$ \\
& $(0.511)$ & $(1.162)$ \\
GCC Gov. Spending Per Capita & $0.427 * * *$ & 0.089 \\
& $(0.079)$ & $(0.138)$ \\
US Federal Fund Rate & $0.036^{*}$ & $0.039 * *$ \\
& $(0.019)$ & $(0.013)$ \\
$R^{2}$ & & 0.52 \\
Sample & 0.56 & 102 \\
\hline
\end{tabular}

Notes: 1. All variables except the Federal Fun Rate are in logarithm form. 2. ${ }^{* * *}$ indicates significant at the 0.01 level, ** indicates significant at the 0.05 level and * indicates significant at the 0.1 level. 3 . Robust standard errors are reported in parentheses. 
Table 4: Elasticity of Remittances: GDP Per Capita Regions

\begin{tabular}{|c|c|c|}
\hline Variable & OLS & $\mathrm{FE}$ \\
\hline Price of Oil & $\begin{array}{c}0.557 * * * \\
(0.140)\end{array}$ & $\begin{array}{l}0.351^{*} \\
(0.170)\end{array}$ \\
\hline GDP per Capita East Asia and Pacific & $\begin{array}{c}0.474 \\
(0.998)\end{array}$ & $\begin{array}{c}1.346^{* *} \\
(0.404)\end{array}$ \\
\hline GDP per Capita South Asia & $\begin{array}{c}0.001 \\
(0.998)\end{array}$ & $\begin{array}{c}-1.959 * * \\
(0.542)\end{array}$ \\
\hline GDP per Capita Sub Saharan Africa & $\begin{array}{c}-3.379 * \\
(1.791)\end{array}$ & $\begin{array}{l}-1.989 \\
(2.927)\end{array}$ \\
\hline GCC Gov. Spending Per Capita & $\begin{array}{c}0.442 * * * \\
(0.079)\end{array}$ & $\begin{array}{c}0.104 \\
(0.133)\end{array}$ \\
\hline US Federal Fund Rate & $\begin{array}{l}0.036^{*} \\
(0.019)\end{array}$ & $\begin{array}{c}0.033 \\
(0.019)\end{array}$ \\
\hline$R^{2}$ & 0.58 & 0.55 \\
\hline Sample & 102 & 102 \\
\hline
\end{tabular}


Figure 1: Interest rates

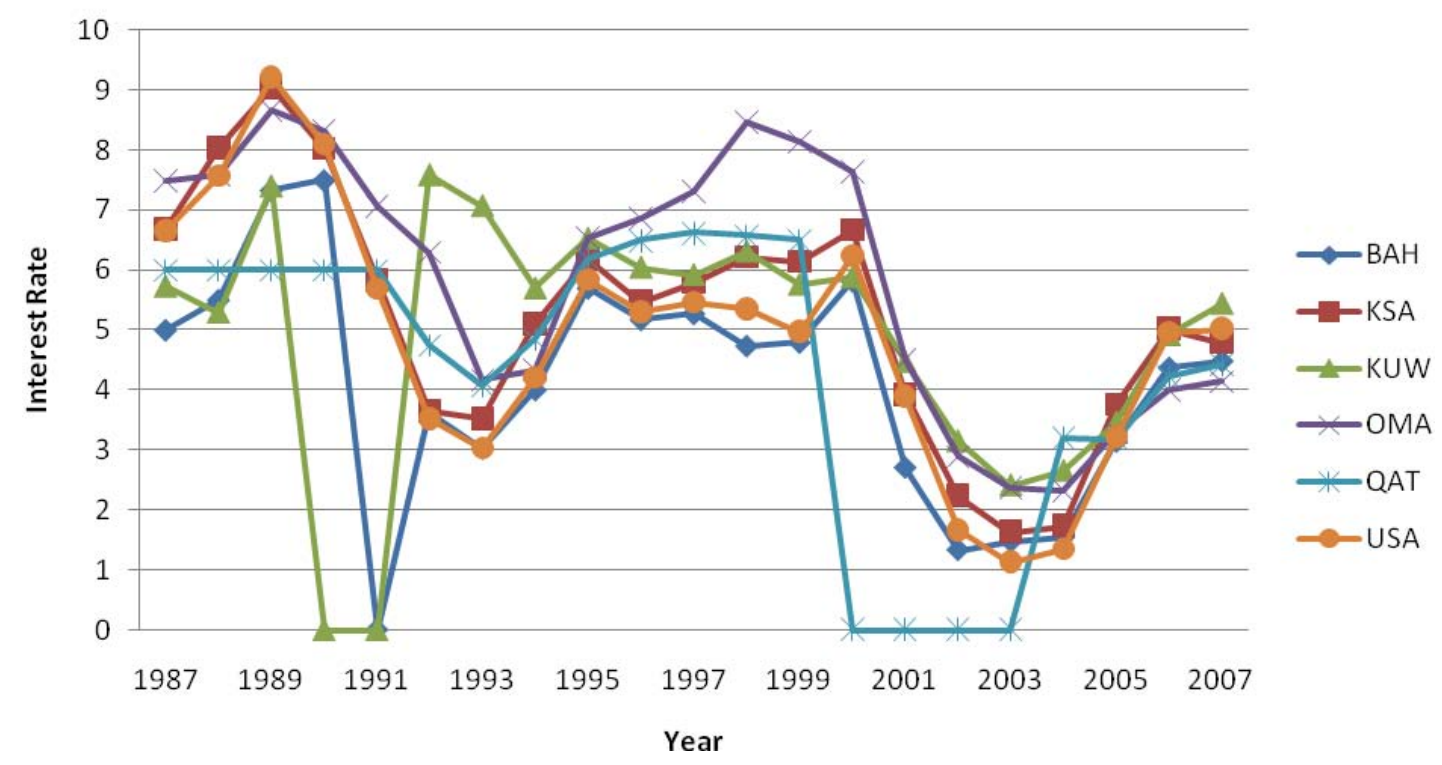

Figure 2: Net Exports

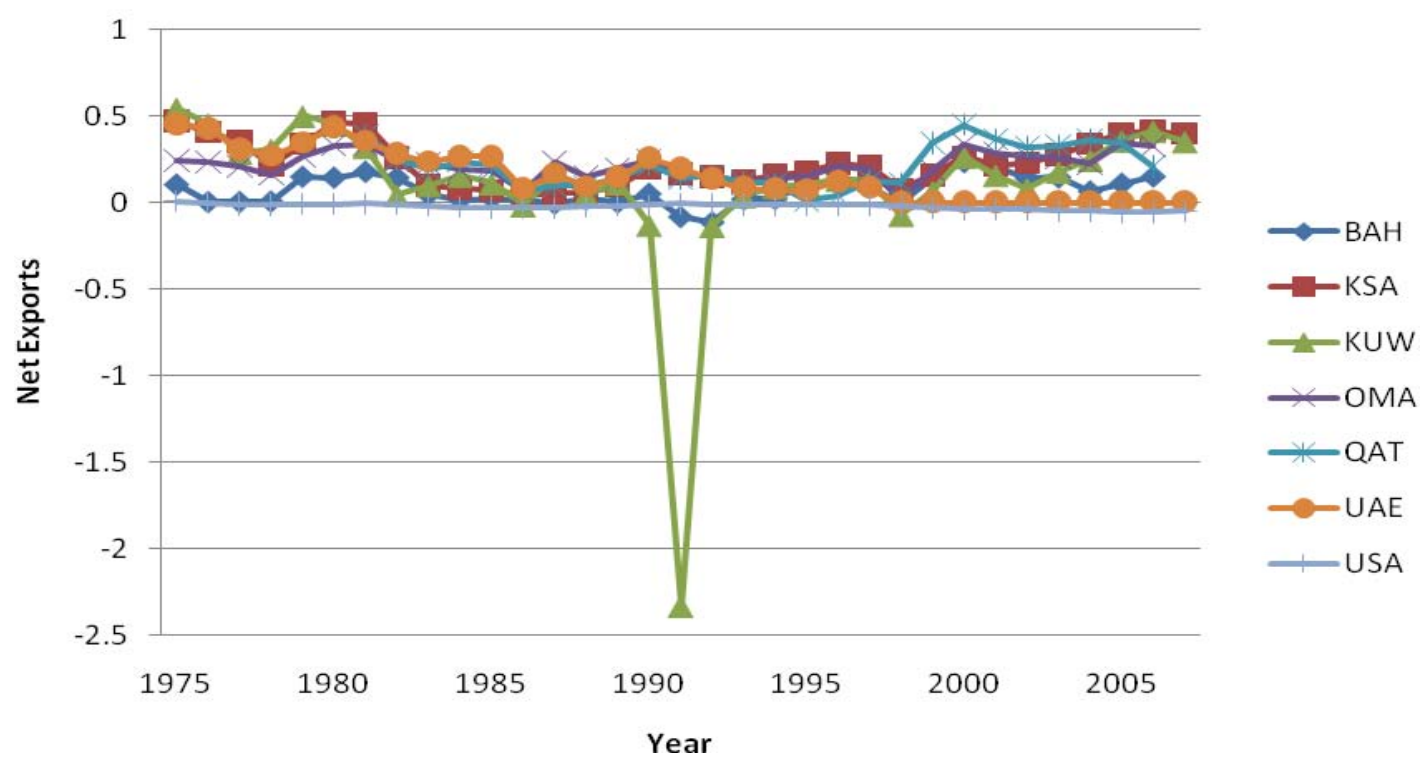




\section{Figure 3:}

$\%$ of Population as Expatriates by Country 2005

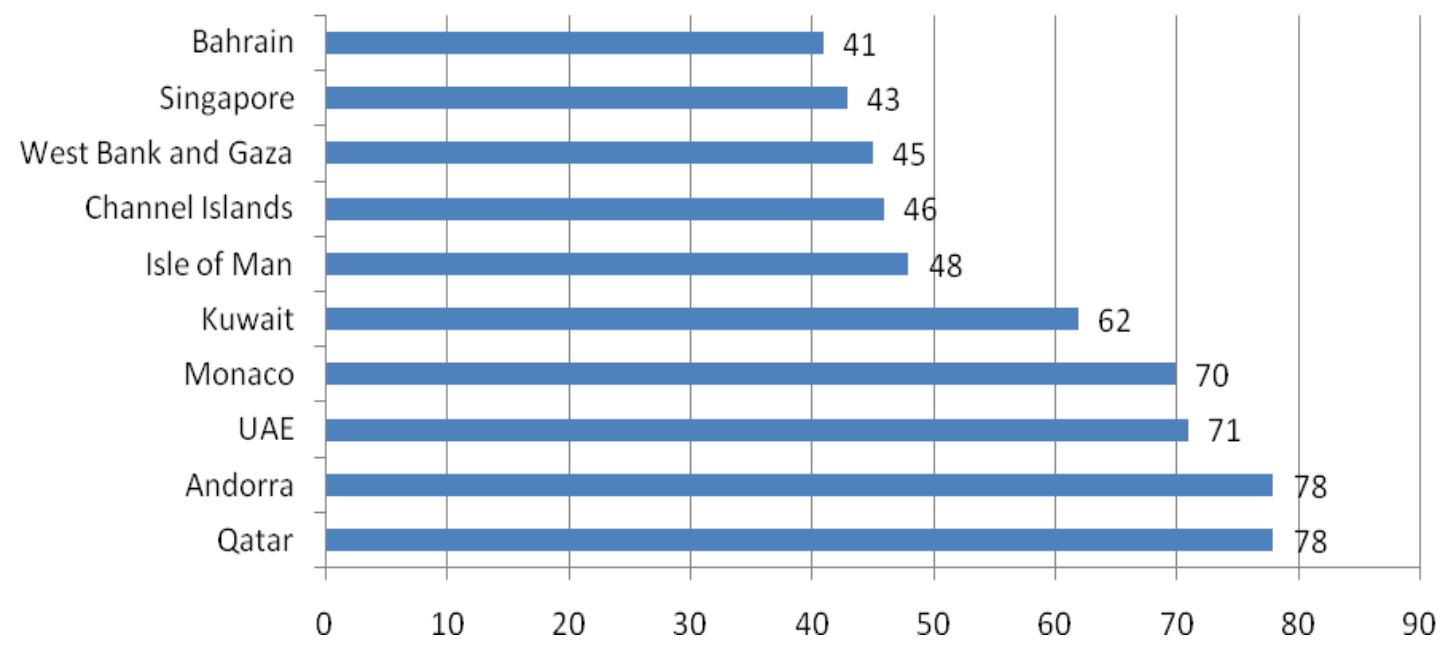

Figure 4: Mean Remittances Per Capita GCC 1971 - 2004

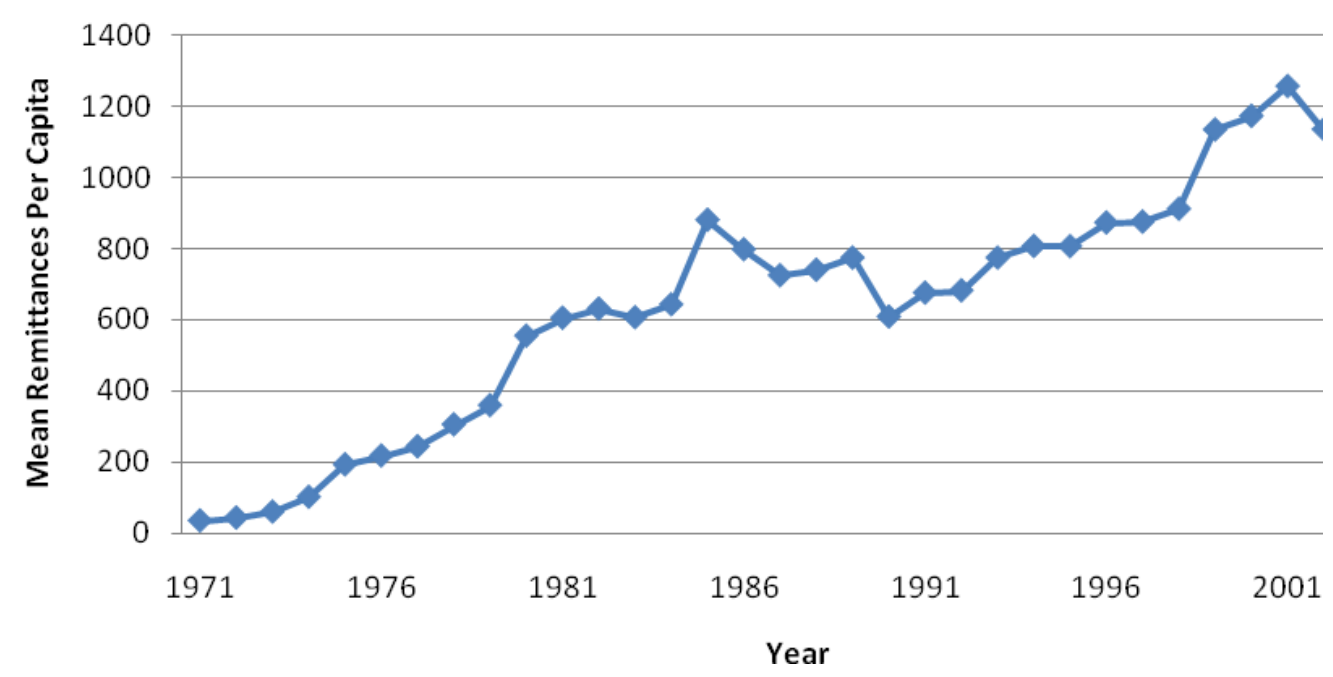


Figure 5: Remittances (dashed) vs. Lag of Price of Oil (straight)

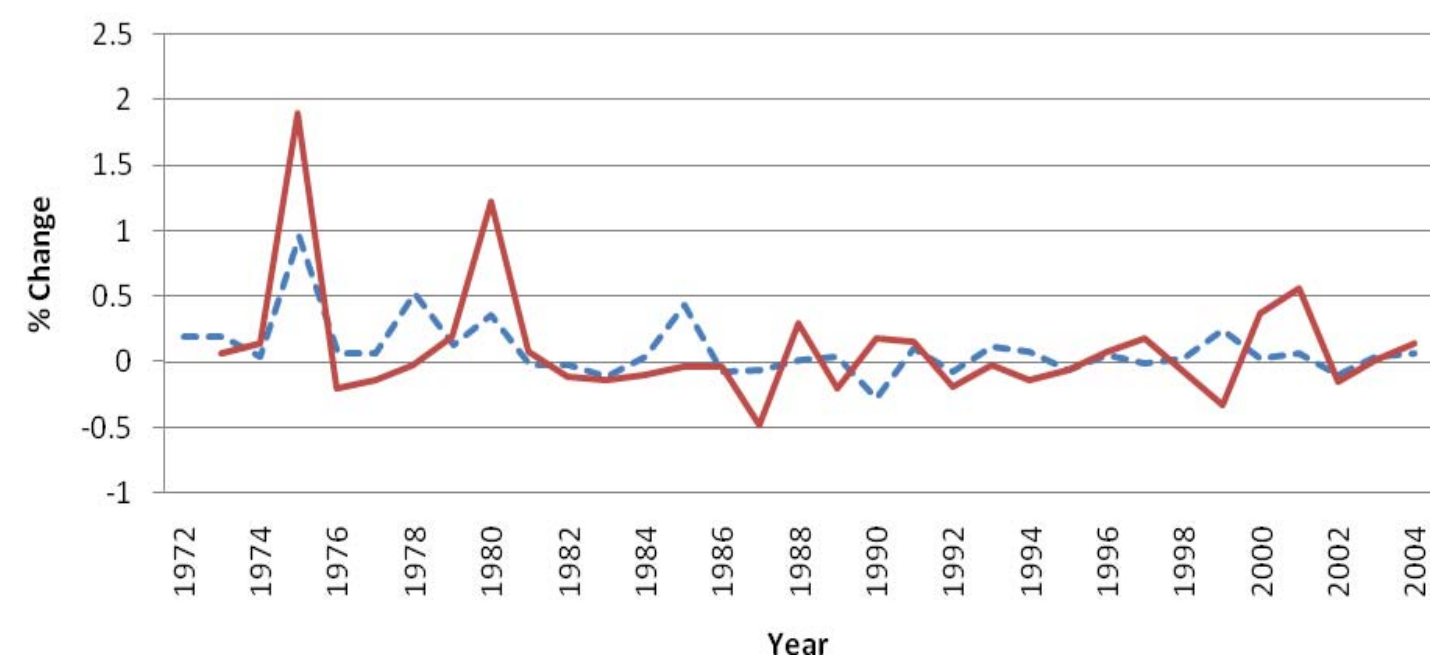




\section{Appendix}

Definitions of Variables

\begin{tabular}{|l|c|}
\hline Variable & Source \\
\hline $\begin{array}{l}\text { Remittances: Workers' remittances and compensation of } \\
\text { employees comprise current transfers by migrant workers and } \\
\text { wages and salaries earned by nonresident workers. }\end{array}$ & $\begin{array}{c}\text { World Development Indicators } \\
\text { (WDI). Arab Monetary Fund } \\
\text { (AMF) for Qatar and UAE }\end{array}$ \\
\hline $\begin{array}{l}\text { Income Per Capita: GDP per capita is gross domestic product } \\
\text { divided by midyear population. }\end{array}$ & WDI, AMF for Qatar \\
\hline $\begin{array}{l}\text { Total Population: Total population is based on the de facto } \\
\text { definition of population, which counts all residents regardless of } \\
\text { legal status or citizenship. }\end{array}$ & WDI \\
\hline $\begin{array}{l}\text { Consumer Price Index: reflects changes in the cost to the } \\
\text { average consumer of acquiring a basket of goods and services } \\
\text { that may be fixed or changed at specified intervals, such as } \\
\text { yearly. }\end{array}$ & WDI, AMF for Oman and UAE \\
\hline Price of Crude Oil: US dollar per barrel & $\begin{array}{c}\text { (International Financial Statistics) } \\
\text { IFS }\end{array}$ \\
\hline US Federal Fund Rate: Federal funds effective rate & $\begin{array}{c}\text { Federal Reserve System Statistical } \\
\text { Release }\end{array}$ \\
\hline
\end{tabular}

